\title{
Pozycja intencjonalna widza: projekcja ciała w pole obrazu
}

ABSTRACT. Majewski Tomasz, Pozycja intencjonalna widza: projekcja ciała w pole obrazu [Intentional position of the spectator: projection of a body into the area of the image]. "Przestrzenie Teorii" 6, Poznań 2006, Adam Mickiewicz University Press, pp. 39-50. ISBN 83-232-1703-3. ISSN 1644-6763.

Our own body, both as a physical object (Körper) and as a focus experiencing sensations (Leib) is usually the axis of our self-identification. In this the mode of presentation of one's own body, in correlation of its accessibility "from the outside" and "from the inside", in which I receive my own body as one and the same, however, one cannot find an answer to the question about how can the bodily (corporal) identification be constituted, which does not have a uniaxial character as it is, e.g. in case of the painterly perception of trompe-l'œil or during the film showing. Projection of one's own body, as is suggested by phenomenological studies of Edith Stein and Leopold Blaustein, may consist in suspending the direct relation to Körper when the basis of identification is merely Leib, which we experience in dislocation, in an unclear connection with the border of the field of imagined space. An important feature of this situation is that during projection of the spectator's body into the field of an image to suspension is submitted not only the feeling of the body as a physical datum, but also space which remains as its real surrounding. The problems touched upon here can be considered as prolegomena to the phenomenology of a spectator-in-aspectacle.

W widzeniu rzeczy cieleśnie obecnych jest założona od samego początku współobecność: obecność tego, co widzę i obecność mnie, który widzi. Ta podwójna obecność jest obecnościq tu - to jest w jednym kontinuum przestrzennym, oraz obecnościq teraz - równoczesnością, czyli wspólną teraźniejszością widzącego i widzianego. W takim akcie widzenia współobecność wykłada się jako współprzynależność. Natomiast współprzynależność, jaką wnosi ze sobą widzenie, jest strukturą pierwotniejszą niż wyodrębniony „podmiot” i „przedmiot”, gdyż są mi one zawsze dane razem i niezależnie od tego, gdzie postawi się w widzeniu akcent, jedno drugiego nigdy nie może wyprzedzić. Dualizm obecności widzącego i widzianego w percepcji bezpośredniej jest pozorny także dlatego, że nie sposób zazwyczaj wykluczyć wzajemności - to znaczy, odwrócenia tego stosunku, bądź pojawienia się kogoś jeszcze, kto widzi także mnie, stąd sama świadomość takiego możliwego odwrócenia nadaje już sytuacji rys potencjalnej wielobiegunowości. Potencjalne przekształcenie mnie samego w przedmiot cudzego widzenia, moje ukonstytuowanie się w zewnętrzność dla kogoś, kto może mnie doświadczyć w ten sposób jest tym, co współtworzy realność sytuacji. Realność jest tu zatem 
zawisła od faktu, że może pojawić się ktoś, kto odwzajemni moje spojrzenie ${ }^{1}$.

Jeśli istnieje tkanka cielesności - pisze Merleau-Ponty - to znaczy, jeśli ukryta strona sześcianu promieniuje gdzieś tak samo jak ta, którą mam przed oczyma, i wspólistnieję z nią, i jeśli ja, który widzę sześcian, należę także do rzeczy widzialnych, jeśli można mnie skądinąd zobaczyć, jeśli on i ja, razem zanurzeni jesteśmy w jednym „żywiole" - czy powinniśmy powiedzieć w żywiole widzącego, czy widzialnego? - to ta spójność, ta zasadnicza widzialność przeważa nad wszelką zasadniczą rozbieżnością 2 .

W percepcji bezpośredniej dzięki tej możliwej odwracalności istnieje układ wzajemnej gwarancji, który sprawia, że fakt pojawienia się czegoś we wspólnej przestrzeni jest nieproblematyczny: przedmiot widzenia istnieje, bo jest przez kogoś widziany oraz zawsze ktoś inny także widząc ów przedmiot, może moje widzenie potwierdzić; widzenie jest natomiast dlatego widzeniem (a nie fantazją), bo istnieje tu i teraz obecne to, co w widzeniu jest postrzegane - to znaczy zawiera ono od samego początku tezę tetyczną, tezę o istnieniu tego, co uchwytuje ${ }^{3}$.

Postrzeganie jest właśnie takim rodzajem aktu, w którym nie może być mowy o oddzieleniu samego aktu od przedmiotu, którego on dotyczy. Percepcja i przedmiot percepcji mają z konieczności tę samą modalność egzystencjalną, skoro nie bardzo wiadomo, jak rozgraniczyć sam akt percepcji od świadomości dotarcia do samej rzeczy i uchwycenia jej. Nie może być mowy o pewności percepcji bez jednoczesnej pewności rzeczy postrzeganej. Jeśli widzę popielniczkę w petnym sensie stowa "widzieć", popielniczka musi się tam znajdować i nie mogę stłumić tego faktu. Widzieć to znaczy widzieć coś. Widzieć kolor czerwony to widzieć czerwień istniejącą in actu. Można sprowadzić widzenie do zwykłego domniemania widzenia wtedy jedynie, gdy przedstawimy je sobie jako kontemplacje płynnego i niezakotwiczonego quale. Lecz jeśli [...] sama jakość w swej specyficznej tkance jest wysuniętą pod naszym adresem sugestią pewnego sposobu istnienia [...], to w jaki sposób moglibyśmy oddzielić pewność naszej postrzegającej egzystencji od pewności jej zewnętrznego korelatu? Zasadniczą sprawą dla mojego widzenia jest to, że odnosi się ono nie tylko do czegoś, co w widzeniu domniemane, lecz właśnie do aktualnie widzianego bytu. I na odwrót, jeśli zrodzi się we mnie wątpliwość co do obecności rzeczy, wątpliwość ta będzie dotyczyła samego widzenia ${ }^{4}$.

1 Przypomnijmy, że takie intencjonalne „odwzajemnienie” jest według W. Benjamina konstytutywne dla doświadezenia aury obiektu. Por. W. Benjamin, O kilku moty. wach u Baudelaire'a (II), przeł. B. Surowska, „Przegląd Humanistyczny”, 1970, nr 6, s. $113-114$.

${ }^{2}$ M. Merleau-Ponty, Widzialne $i$ niewidzialne, przekład zbiorowy, wstęp i oprac. J. Migasiński, Warszawa 1996, s. 144.

${ }^{3}$ Merleau-Ponty określa to jako „pierwotną wiarę postrzeżeniową”.

${ }_{4}^{4}$ M. Merleau-Ponty, Fenomenologia percepcji, przeł. M. Kowalska i J. Migasiński, Warszawa 2001, s. 396. 
W wypadku widzenia czegoś zobrazowanego fenomenologiczny charakter sytuacji jest odmienny. Po pierwsze, obraz nie jest dla mnie przedmiotem $\mathrm{w}$ przestrzeni takim jak inne. Jest mi nawet trudno sobie wyobrazić, abym mógł widzieć tu jedynie materialny przedmiot, nie widząc zarazem tego, co on ukazuje. Niezwykłe wydaje mi się cały czas to, $\mathrm{w}$ jakiej relacji pozostaję $\mathrm{w}$ stosunku do tego, co tam - to znaczy w obrazie - teraz widzę.

Zwierzęta malowane na ścianach Lascaux nie znajdują się tam w ten sposób, co obecne na nich pęknięcia lub nacieki wapnia. Nie są też gdzie indziej. Nieco w przodzie, nieco w tyle, podtrzymane ścienną masą, którą sprytnie i zręcznie wykorzystują. [...] Z trudnością przyszłoby mi powiedzieć, gdzie jest malowidło, na które spoglądam. Albowiem nie patrzę na nie w ten sposób, w jaki patrzę na jakąś rzecz; nie unieruchamiam go w miejscu, jakie zajmuje; [...] nie tyle je widzę, ile raczej według niego lub wraz z nim 5 .

To, co postrzegam, aby być widziane w sposób nie budzący żadnych wątpliwości, wymagałoby mojego uobecnienia w innym polu fenomenalnym: tym, które ewokuje przestrzeń obrazu. Widzę aktualnie coś, czego Ja jako Ja, w samotożsamości z sobą, cielesnym, w przestrzeni, którą zajmuję, nie powinienem teraz $i$ tutaj widzieć. To, co istnieje ukazane na obrazie, nie pozostaje w żadnej uchwytnej relacji do innych przedmiotów obecnych cieleśnie wokół mnie. Nie pozostaje także w jednoznacznej relacji do mojego ciała. Przestaje tutaj obowiązywać zasada, że wszystko, co znajduje się w polu mojego wzroku, znajduje się także w pewien sposób w moim zasięgu, to znaczy pozostaje jakoś dostępne dla moich projektów, będąc już automatycznie „naniesione na mapę mojego "mogę»"6. Swiat widzialny oraz świat motorycznych projektów rozdzielają się?. Nie zmienia to w niczym faktu, że zarówno to, co na obrazie, jak i to, co wokół mnie postrzegam, to znaczy widzę to. Tym samym jednak sens słowa „widzieć” nagle rozwidla się i zaczyna znaczyć dwie całkiem różne rzeczy. Tego, co ukazane na obrazie, nie widzę przecież $\mathrm{w}$ tym samym znaczeniu, w jakim widzę książki na moim biurku i przygotowane do pisania ołówki - te ostatnie pozostają bowiem przez cały czas w zasięgu ręki, są nieproblematycznie obecne $\mathrm{i}$ już teraz wciągnięte $\mathrm{w}$ możliwy projekt: uchwycenia ich, i użycia przy wynotowywaniu z książek potrzebnych mi uwag.

Mam zatem dwa różne pola widzenia, których nie mogę uzgodnić. Każde z tych pól jest zarazem moim polem, ale i też każde

5 M. Merleau-Ponty, Oko i umyst. Szkice o malarstwie, wybrał i oprac. S. Cichowicz, Gdańsk 1996, s. 24-25.

6 Tamże, s. 21.

7 Tamże. 
z nich implikuje jak gdyby całkiem innego mnie. Postrzegając w polu obrazu, osadzam siebie w całkowicie nowym ośrodku widzialności, różnym od tego, z którym pozostaje powiązane moje fizyczne ciało. Rozwidlający się sens "widzę" prowadzi w konsekwencji do rozwarstwienia rozumienia ,ja" i utraty samooczywistości normalnie zachodzącej jednoosiowej identyfikacji. „Znajduję się w zaiste trudnej sytuacji. Z jednego z dwu twierdzeń, w których prawdziwość wierzę, muszę w tym wypadku zrezygnować. Albo zaprzeczę temu, że przedmioty, wypełniające każdy odcinek przestrzeni, a przeze mnie widziane, grupują się jakby dookoła mego ciała, albo przestanę wierzyć w to, że przedmiot pozostający w stosunkach przestrzennych do jednego przedmiotu przestrzennego, pozostawać w nich musi również do wszelkich innych"8. Z sytuacji tej znajduję wyjście dopiero wtedy, gdy powiem, że -

ów dom, most, wieże i góry grupują się przed moim ciałem, ale nie przed tym oto siedzącym na krześle przy biurku, lecz jak gdyby rzutowanym w ów świat, który odsłania mi się przy patrzeniu na obraz. Jestem tam, choć niewidoczny. Mogę nawet określić dokładnie miejsce, w które siebie rzutuję. Po tej oto stronie mostu, której nie widzę, w tym miejscu, gdzie stałby fotograf resp. malarz, chcąc fotografować lub malować widziane przeze mnie przedmioty ${ }^{9}$. Nie jestem ja albo raczej mój Sehding tam taki wielki, jak obecnie swe ciało postrzegam, lecz taki malutki, jak ten człowiek, który stoi na ulicy przed domem, taki, jak koniec ołówka, którym piszę. I dlatego właśnie, iż siebie tak - nieświadomie zresztą - rzutuję, widzę dom ten jako większy ode mnie, choć w porównaniu do mego ciała, siedzącego na krześle, jest ponad sto razy mniejszy. To moje ciało tam rzutowane, na niewidocznej mi stronie mostu stojące, nie pozostaje w żadnych stosunkach przestrzennych do mego ciała siedzącego przy biurku. I w ogóle świat przestrzenny, w którym znajdują się owe góry, domy i wieże, które widzę, patrząc na obraz, znalazły się jako obcy, natrętny przybysz w przestrzeni mnie otaczającej, nie pozostając do niej w żadnych stosunkach ${ }^{10}$.

${ }^{8}$ L. Blaustein, Przedstawienia imaginatywne. Studium z pogranicza psychologii i estetyki, Nakładem Polskiego Towarzystwa Filozoficznego, Lwów 1930, s. 18.

9 Zob. uwagę, która idzie dalej: „Malarz «wnosi swoje własne ciało», powiada Valery. I rzeczywiście trudno sobie wyobrazić, żeby Umysł mógł malować. Oto użyczając swego ciała światu, malarz przemienia świat w malarstwo. Aby zrozumieć te transsubstancjacje, trzeba odnaleźć aktualne i operatywne ciało, nie to, które jest wycinkiem przestrzeni, pękiem funkcji, ale które jest splotem widzenia i ruchu. [...] Skądinąd prawdą jest równieź, że widzenie jest zawisłe od ruchu. Widzi się tylko to, na co się spoglada”. M. Merleau-Ponty, Oko $i$ umyst: Szkice o malarstwie, op. cit., s. 20-21. Analiza zjawiska projekcji ciała musi być uzupełniona przez badanie sposobów skierowania uwagi, zarówno skierowania wzroku fizycznego, jak i ukierunkowania na pewien sens samego postrzeżenia. Chodzi jednym słowem o analizę ruchu intencji widza.

${ }^{10}$ L. Blaustein, Przedstawienia imaginatywne, op. cit., s. 18-19. 
W doświadczeniu tym, które charakteryzuje wskazane „podmiotowe rozszczepienie" może dochodzić do swoistej decentracji i zwielokrotnienia naszej pozycji.

Ciało moje - pisze Blaustein - może się nie tylko „rozdwoić”, lecz również „roztroice" itd., na przykład w wypadku oglądania własnej fotografii, gdy intenduję do przedmiotu imaginatywnego. Odróżnić bowiem wówczas należy A) moje ciało w rzeczywistej przestrzeni, B) moje ciało jako przedmiot imaginatywny, C) moje ciało rzutowane; A jest dane w postrzeżeniu, B w przedstawieniu imaginatywnym $\mathrm{C}$ w ogóle nie jest mi dane i dane mi być nie może. Gdybym utworzył je wytwórczo $w$ fantazji, uzupełniając świat imaginatywny, musiałbym rzutować ponownie moje ciało, cofnęłoby się ono jakby w tyl, a to czwarte ciało D nie byłoby już dane $\mathrm{e}^{11}$

Analiza Blaustein wymaga rozjaśnienia, nie jest bowiem nadal jasne, czym jest „ciało rzutowane”. Możemy spróbować do tego dojść drogą eliminacji, ponieważ Blausteinowskie ciało A (w przestrzeni fizycznej) i B (ciało wyobrażone) będzie nam łatwiej scharakteryzować, niż C czyli „ciało rzutowane”. Spróbujmy najpierw wskazać, w jaki sposób prezentuje się naszej świadomości ciało, które odbieramy jako „nasze własne ciało". Na najbardziej elementarnym poziomie możemy wskazać na dwa sposoby prezentacji: postrzeganie zewnętrzne i odczucie wewnętrzne własnego ciała. Po pierwsze, ciało nasze nigdy nie może być nam dane jedynie poprzez samo spostrzeżenie zewnętrzne.

Jeżeli [...] przyjmiemy [tę] fikcję, jakobyśmy je mieli dane jedynie w ten sposób, to buduje się nam jakiś w najwyższym stopniu osobliwy obiekt. Rzecz realna, ciało fizyczne (Körper) [tj. Blausteinowskie ciało A - przyp. T.M.], którego szeregi przejawów wykazują przedziwne luki [...], które drwi sobie ze mnie, wzywając mnie do oglądania go z coraz to nowej strony, a skoro chcę pójść za tym wezwaniem, [to] ukrywa przede mną te strony. Wprawdzie to, co uchyla się przed spojrzeniem, jest dostępne dotykającej ręce; ale właśnie ten stosunek widzenia i dotykania jest inny niż przy wszystkich innych rzeczach ${ }^{12}$.

W przypadku bowiem innych rzeczy materialnych prezentacja wzrokowa może zawsze zostać zweryfikowana przez dotyk, to znaczy mogę uchwycić ręką to, co widzę; w przypadku natomiast ciała własnego pewne jego partie (np. plecy) są mi dane jedynie dotykowo, nie mogę więc wymienić tu danych wzrokowych na dotykowe. Ciało moje pojmuję jednak jako całość, pomimo że każdy inny obiekt, który by mi się również prezentował w tak nieciągły sposób, uznałbym za „zdekompletowany” i niemożliwy (nie istniejący). Możliwość uchwycenia danych nam jedynie

11 Tamże, s. 18, w przypisie.

12 E. Stein, O zagadnieniu wczucia, przeł. D. Gierulanka i J.F. Gierula, Kraków 1988, s. $61-62$. 
dotykowo partii własnego ciała np. w lustrze niczego nie zmienia: gdybym nie miał danego już wcześniej wewnętrznego poczucia integralności mojego ciała, tym bardziej nie umiałbym zintegrować tego wyalienowanego obrazu, który jest „tam”, z moim ciałem, które jest „tu” - nie byłoby bowiem wtedy żadnej możliwości przejścia od obrazu fragmentu ciała, do uchwycenia jego sensu jako fragmentu mojego ciała13. "Ciało spostrzeżone tylko zewnętrznie byłoby zawsze jedynie pewnym, szczególnego rodzaju [...] fizycznym ciałem, ale nigdy "moim ciałem»"14. Ten rys dania ciała własnego naszej świadomości ma także swoje znaczenie dla możliwości rozpoznania siebie jako kogoś przedstawionego w obrazie wizualnym (Blausteinowskie ciało B). „Można wykazać, że nie rozpoznajemy własnej ręki na fotografii, [...] ale każdy rozpoznaje na filmie swoją sylwetkę lub swój sposób chodzenia. Tak więc, nie rozpoznajemy wzrokiem tego, co przecież często widzieliśmy, natomiast od razu rozpoznajemy wizualne przedstawienie tego, co w naszym ciele jest dla nas niewidoczne"15.

Zatem zarówno moje ciało jako ciało fizyczne (Körper), jak i to ciało jako jego wizualizacja, wymagają jakiegoś wcześniejszego, wewnętrznego zidentyfikowania się ze swoim ciałem, która to identyfikacja dopiero pozwala mi przyjąć to właśnie ciało materialne jako „ciało własne”, a jego wizualizację w przedstawieniu jako „reprezentację materialnego ciała”, które jest tożsame z żyjącym ciałem własnym (Leib). Na czym więc polega ten wewnętrzny sposób prezentacji ciała, które świadomości przedstawia się jako ciało własne? Po pierwsze, mogę powiedzieć - odwołując się tu również do spostrzeżenia zewnętrznego - że wszystkie inne ciała są mi dane raz jako dalsze, raz jako bliższe. Raz są mi dane, kiedy in-

${ }^{13}$ Dlatego uważam, że Lacanowską „fazę zwierciadła” należy rozumieć jako metaforę jednego z etapów procesu konstytucji jaźni. Nie ma natomiast sensu traktowanie jej dosłownie (jako opisu mechanizmu percepcji), jak to czyniła psychoanalityczna teoria filmu. Dokładniejsze przyjrzenie się sprawie pokazuje, że nie jest możliwym uzyskanie spójnego obrazu własnego ciała oraz siebie jako ucieleśnionego, gdyby próbować tego dokonać w oparciu o spostrzeżenie zewnętrzne, zapośredniczone w czymś, co jest „w" lustrze. Jako opis konstytucji świadomości ciała na tym zupełnie elementarnym poziomie, wywód Lacana byłby nieprzekonujący. Sprawa ma się natomiast przeciwnie, gdy będziemy konstytucję rozumieć jako konstytucja samoświadomości - po pierwsze „obraz mnie” uzyskuję tu jako obraz Innego, czyli podstawą identyfikacji jest utożsamienie z nie-sobą. Po drugie percepcyjnie uzyskana „forma ciała”, będąca podstawą dalszej relacji wyobrażeniowej „siebie z sobą", od początku nie pokrywa się z apercepcją (bo sama apercepcja we właściwym znaczeniu tego słowa pojawia się dopiero „po" błędnej „identyfikacji percepcyjnej” i to na bazie tejże). Mamy tu niewątpliwie do czynienia $\mathrm{z}$ metaforycznym ujęciem genezy podmiotu, a nie z empiryczną sytuacją percepcji zmyslowej.

14 E. Stein, O zagadnieniu wczucia, op. cit., s. 63.

15 M. Merleau-Ponty, Fenomenologia percepcji, op. cit., s. 170. 
dziej już wcale nie. Natomiast to ciało jest mi zawsze "cieleśnie" dane, jest dla mnie zawsze obecne, jest czymś, co „mam”, nawet wtedy, kiedy się ku niemu nie kieruję. Ciało to jest mi dane jako ciało doświadczające wrażeń, które odczuwam. Ciepło i zimno, ból i przyjemność, twardość i nacisk przychodzą do mnie poprzez to ciało. Są one doznawane przeze mnie $w$ nim: rozdzielam te aspekty, ponieważ chociaż to ja jestem doświadczającym ciałem, ale to ciało nie jest już w całym zakresie mną:

... wrażenie odznacza się w stosunku do wszystkich [...] aktów [takich jak: sądzenie i chcenie] czymś szczególnym, nie wypływa ono, tak jak tamte, z czystego Ja, nie przybiera nigdy formy "cogito", w którym Ja kieruje się na pewien obiekt, nigdy więc nie mogę - zwracając na nie refleksję - znaleźć w nim Ja, lecz zawsze jest ono „gdzieś” przestrzennie zlokalizowane, oddalone od Ja, być może bardzo blisko niego, ale nigdy w nim. A to "gdzieś" nie jest pustym miejscem w przestrzeni, lecz czymś wypełniającym przestrzeń; i wszystkie te „co", na których występują moje wrażenia, zespalają się w pewną jedność, jedność mojego ciała, one same są miejscami ciała. W obrębie tego stanowiącego jedność prezentowania się [...] różne części ciała, które mi się wrażeniowo konstytuują, są rozmaicie oddalone ode „mnie”. I tak tułów jest bliższy „mnie” niż kończyny i sensownie mogę powiedzieć, że przybliżam [swe] ręce albo oddalam [od siebie] ${ }^{16}$. Gdy mówię o oddaleniu ode "mnie”, jest to niedokładny sposób wyrażenia się, właściwie nie mogę skonstatować jakiegoś odstępu od „Ja”, (...) ale części mojego ciała i w ogóle wszystko, co przestrzenne w nim, odnoszę do pewnego „zerowego punktu zorientowania”, który jest otoczony przez moje ciało; ten punkt zerowy nie da się geometrycznie zlokalizować w pewnym miejscu mojego ciała fizycznego, poza tym nie jest on ten sam dla wszystkich danych [zmysłowych], lecz dla wzrokowych jest położony w głowie, dla dotykowych w środkowej partii ciała ${ }^{17}$.

To, co bliskie i to, co dalekie, dla mnie w moim własnym ciele jest takie w innym sensie niż dystans innych rzeczy materialnych względem siebie oraz ich przestrzenny dystans do mnie. Żadnej rzeczy nie mogę tak bardzo zbliżyć do siebie, aby była ona odczuta jako będąca cieleśnie "mną". Istnieje zawsze pewien rozstęp pomiędzy rzeczą, która jest „na zewnątrz" i ciałem, które jest odczute „od wewnątrz”. Podobny hiatus można zaobserwować nawet wtedy, gdy dotykamy ręką własnego ciała. Rękę i fragment ciała, który jest przez nią dotykany, odczuwamy zgoła różnie: moja ręka teraz dotyka (jest skierowana ku...), a to, czego ona dotyka, doświadczam od wewnątrz jako mojego ciała, które jest przez tę własną rękę dotykanym. Moje ciało ma za-

${ }^{16}$ Według J. Lhermitte w L'Image de notre corps: „Każdy z nas widzi siebie jakby okiem wewnętrznym, które z kilku metrów ogląda nas od głowy do kolan”. Zob. M. Merleau-Ponty, Fenomenologia..., op. cit., s. 170.

${ }^{17}$ E. Stein, O zagadnieniu wczucia, op. cit., s. 63-64. 
tem dla mnie wewnętrzną i zewnętrzną stronę, których nigdy nie udaje mi się do końca ze sobą utożsamići ${ }^{18}$.

Spostrzegając tylko zewnętrznie - pisze Edith Stein - nie doszłabym do pierwszej z nich, tylko „cieleśnie spostrzegając” nie doszłabym do drugiej. Ponieważ jednak moje ciało konstytuuje się $\mathrm{w}$ dwojaki sposób - jako doznające wrażeń (cieleśnie spostrzegane) ciało (Leib) i jako zewnętrznie spostrzegane fizyczne ciało (Körper) [w obrębie] zewnętrznego świata - i w tym podwójnym prezentowaniu się jest przeżywane jako to samo, [dlatego] też uzyskuje pewne położenie $\mathrm{w}$ zewnętrznej przestrzeni, wypełnia jakąś część tej przestrzeni $^{19}$.

W opisanym powyżej sposobie dania nam ciała własnego, w tej korelacji dania „z zewnątrz" i „od wewnątrz”, w którym to podwójnym sposobie prezentacji odbieram własne ciało jako jedno i to samo, nie można na razie znaleźć odpowiedzi na pytanie, o to, jak może się ukonstytuować identyfikacja cielesna, która nie ma już charakteru jednoosiowego. Projekcja ciała własnego polega niewątpliwie na zawieszeniu bezpośredniego związku z Körper, ale jeśli podstawą naszej identyfikacji pozostaje Leib (nadal przecież odczuwamy nasze ciało „od wewnątrz”) to jak należy to rozumieć, że odczuwamy je teraz na granicy przestrzeni zobrazowanej - tak, jak gdybym uzyskiwał od obrazu ulokowane tam nowe ciało? Istotnym rysem sytuacji jest to, że w projekcji w pole obrazu zawieszeniu ulega nie tylko ciało fizyczne, ale i przestrzeń, która pozostaje do niego w relacji. Jak to się dzieje, że kiedy zmieniam pole moich postrzeżeń, to „poczucie ciała” przemieszcza się tam również? Nie podąża ono przecież za percepcją uchwytującą $\mathrm{z}$ zewnątrz inne ciało ludzkie (odpowiednik mojego ciała fizycznego), ale przemieszcza się za percepcjami zmysłowymi obcych obiektów. zewnętrznych, jest zatem tak, jakby odczucie ciała przemieszczało się wraz z ruchem uwagi, która kieruje się ku temu, co widzi. Projekcja ciała zachodzi $w$ oparciu o to, co widze, jak gdyby spostrzeżone obiekty byty wyposażone $w$ sens odsytajacy do tego domniemanego ciała, w jakim ulokowata się moja uwaga. Relacja ciała doświadczanego cieleśnie „od wewnątrz" i ciała fizycznego wymaga zatem poszerzenia o jeszcze jeden aspekt.

Nie tylko widzę swoją rękę i spostrzegam tę samą rękę cieleśnie jako doznającą wrażeń, lecz „widzę" również pola wrażeniowe tej ręki, które mi się ukonstytuowały w cielesnym spostrzeżeniu; a z drugiej strony, gdy zauważając je, uwydatniam części mego ciała, posiadam zarazem "obraz" odpowiedniej części fizycznego ciała wraz z tamtym współdanego,

${ }^{18}$ M. Merleau-Ponty, Widzialne i niewidzialne, op. cit., s. 149-152.

19 E. Stein, op. cit., s. 64-65. 
jakkolwiek nie percypowanego. Coś dokładnie analogicznego mamy w dziedzinie spostrzeżenia zewnętrznego. Widzimy nie tylko stól i dotykamy [raczej: czujemy dotykowo] jego twardość, ale „widzimy” też jego twardość. Stroje na obrazach Van Dycka są nie tylko jedwabiście błyszczące, lecz także jedwabiście gładkie i jedwabiście miękkie ${ }^{20}$.

Oznacza to, że walory zmysłowe obrazu ewokują nie tylko przedmiot zobrazowany, ale też jako współdane z nim - doznające go ciało. Nawet nie jakiś perspektywicznie pojęty „punkt widzenia", ale właśnie ciało, które doznając czegoś z danej mu w prezentacji rzeczy, doznaje $\mathrm{w}$ ten sposób także pośrednio samego siebie ${ }^{21}$. Ewokowane w ten sposób pole danego zmysłu przyzywa stopniowo całą resztę żywego, czującego ciała - tak jak „oko przyzywa dotyk" w wyrażającej się dla nas haptycznie przestrzeni.

$\mathrm{Z}$ fenomenologicznego punktu widzenia obraz jest zatem znacznie rzadziej obrazem czysto wizualnym, to znaczy obrazem doznania tylko i jedynie optycznego, niż mogłoby się to w pierwszej chwili wydawać 22 . Częściej natomiast ewokuje już pewien świat, przez to zaś, że jest to pewien świat, wnosi on ze sobą potencjalnie całość, to znaczy koncentryczne kręgi coraz to dalszych horyzontów jakiegoś możliwego w jego obrębie doświadczenia, co przyzywa także estezjologiczne ciało i ucieleśniony w nim umysł, które mogłoby ten świat - o ile by się w nim już znalazły poznawać.

20 Tamże, s. 66.

${ }^{21}$ Dlatego nie mogę zgodzić się z poglądem J.-L. Baudry'ego, (przejętym następnie przez Ch. Metza w The Imaginary Signifier), że identyfikacja jest identyfikacją z punktem widzenia kamery (błędność tego poglądu wykazały analizy N. Brown), oraz założoną $w$ tym poglądzie pozycją widza jako ja transcendentalnego. Widz-w-spektakłu ma ciało, tyle, że jest to cialo przychodzące $z$ pola możliwej eksploracji ukazanej w obrazie. Sprawa identyfikacji ukazuje się już natomiast z innej strony, gdy rozpatrzymy ją na kolejnych płaszczyznach odniesienia intencjonalnego: afektywnej, aksjologicznej i ogarniającej je płaszczýnie narracyjno-dramaturgicznej.

22 Przy wszystkich przewartościowaniach pojęcia obrazu, które tu proponuję, nie sposób oczywiście zapomnieć, że chodzi o ewokowanie pól innych zmysłów przez wzrok, który jest $\mathrm{z}$ nich wszystkich w największym też stopniu zmystem dystansu. Niewątpliwie dotyk i smak są zmysłami najbardziej zwrotnymi i zarazem najbardziej prywatnymi, to znaczy, że „[...] postrzegając jakiś przedmiot, ciało za pośrednictwem tych zmyslów przede wszystkim odczuwa siebie". H. Arendt, Kondycja ludzka, przel. A. Łagodzka, Warszawa 2000, s. 126. Dlatego też na bazie przedstawienia wizualnego może dochodzić w sytuacji gry do krystalizacji odpowiednika świata wspólnego. Wzrok i sluch jako pola zmysłowe są dostateczną podstawą konstytucji obszaru wspólnego, dlatego realne włączenie innych pobudzen zmysłowych do spektaklu kinematograficznego (na zasadzie dążenia do sensorycznej iluzji) nie utetycznia w bardzo wyraźny sposób świata prezentacji. Zob. N. Burch, Narrative/Diegesis - Thersholds, Limits, „Screen” 1982, vol. $23, \mathrm{nr} 2$, s. 20. 
Pozostaje jeszcze pewien modus percepcji obrazu, który wyraźnie odbiega od opisanego i któremu warto byłoby się bliżej przyjrzeć. Chodzi nam o moment wahania i „oscylacji na krawędzi” pomiędzy wyjściowym polem percepcyjnym i polem obrazu. Widzenie obrazu można wtedy rozumieć jako projekt, gdzie nie doszło do rozstrzygającej aktualizacji i istnieją równorzędne możliwości „czym to widzenie może być”, bo nie zdecydowałem czym będzie - to swoiście estetyczny modus „balansowania na krawędzi przejścia”. Znajdujemy się wówczas jak gdyby na styku dwóch przestrzeni, w miejscu ich interferencji. Przynależymy potencjalnie do dwóch porządków i nie przynależymy na dobre do żadnego $\mathrm{z}$ nich. Ja nie identyfikuje się jednoznacznie $z$ żadnym polem percepcyjnym, zawieszając tym samym oczywistość relacji tożsamości z własnym ciałem i nie przyjmując zarazem identyfikacji z ciałem rzutowanym w obszar obrazu. Swiadomość patrzącego wyznacza granicę obu obszarów, dzięki czemu Ja, bawiąc się, uczestniczy w swobodnej grze możliwości i nie wybiera żadnej, zachowując supremację nad całością tego, co tutaj możliwe.

Wybór określonego pola pociągałby za sobą wybór świata i określonej modalności bycia podmiotem i tym samym redukowałby rolę Ja jako elementu samotożsamego, do którego relatywizowane są pozostałe elementy sytuacji. Ja nie czyni więc żadnego wyboru. Jest to nieprawomocne rozszerzenie konsekwencji bycia limesem na całość rozwijającego się doświadczenia. Między jednym i drugim modus, z których każdy w inny sposób organizuje całą przestrzeń, trzeba faktycznie wybierać. Można, co najwyżej, przechodzić tam i z powrotem, ale nie można być w obu jednocześnie. Każdorazowe przejście od jednego do drugiego porządku odwraca ponownie relację wnętrza i zewnętrza, centrum i peryferii, które to doświadczenie Walter Benjamin bardzo trafnie przyrównuje do wywracania pończochy. Mamy możliwość ujmowania tego, co się prezentuje w obrazie, bądź wychodząc intencjonalnie od przestrzeni fizycznej, którą zajmujemy i - co ważniejsze - od swojej tożsamości z samym sobą, bądź wychodząc od nowej pozycji, jaką wyznacza nam przestrzeń ewokowana w obrazie. Podstawą doświadczenia obrazu można uczynić to, co w nim się prezentuje wraz z konstelacją relacji, jakie prezentacja wnosi ze sobą, lub przeciwnie, wyjść od niezbywalnego poczucia własnej jaźni i jej roli jako ontycznego centrum wszystkich możliwych relacji. Ta niejednoznaczność, umożliwiająca przyjęcie całkowicie odmiennych orientacji sprawia, że obraz można rozumieć: raz jako uobecnianie się czegoś $w$ mojej przestrzeni (bądź przedmiotowo: jako obraz-obiekt lub quasi-przedmiotowo jako iluzja obecności w tej przestrzeni przedmiotu zobrazowanego), a raz jako moje uobecnienie się - moje zjawienie się $w$ przestrzeni, jakq ewokuje pole obrazu. Chodzi o dwie modalności ist- 
nienia jednego i tego samego bytu. Obraz istnieje jako przedmiot naszej intencji i naszego spojrzenia, bądź istnieje jako pole widzenia, które konstytuuje tożsamość samego widzącego w nowy dla niego sposób. Obraz to byt, który może zostać włączony na sposób przedmiotowy $\mathrm{w}$ gotowe i poprzedzające jego pojawienie się pole podmiotowe bądź też podmiot może „być włączony” $w$ pole intencjonalne obrazu i zająć pozycję na nowej orbicie grawitacji wokół centrum, jakie ustanawia intencja obrazu. Innymi słowy, podmiot może narzucić tu swoje własne reguły gry bądź przyjąć reguły gry obrazu. Może też przechodzić od jednej do drugiej pozycji bawiąc się tą sytuacją na sposób estetyczny.

Przyjęcie „odwróconej perspektywy" intencjonalnej - perspektywy zobrazowanego - nie oznacza anihilacji podmiotu. Ta pozycja zakłada bowiem nie tyle „dekonstrukcję” podmiotu, co raczej jego epoche i „rekonstrukcję" na nowych zasadach. Zgodnie z określeniem Ricoeura zamieniamy wówczas ja (moi) pana-niego-samego na jaźń (soi) ucznia prezentującego się świata ${ }^{23}$. Wszelako istnienie takie wymaga postawy polegającej na antycypującym wychyleniu ku możliwości bycia dosięgniętym przez coś różnego od nas. Otwartość i pasywność tworzą elementarne warunki przyswojenia sobie nowego sensu: reorientują sytuację i pozwalają przejść od egologicznego modelu doświadczenia do modelu dialogicznego.

W tym sposobie doznawania - pisze Ingarden - nie uświadamiamy sobie także, że to, co odczuwamy lub odbieramy, jest jakoś od nas, doznających, różne. [...] O jakimkolwiek „przedmiocie intencjonalnym”, który by się odcinal jakoś od prostego płynięcia w strumieniu dat wrażeniowych i który przeciwstawiałby się doznającemu ,ja" (stanowiącemu jakąś całostkę odrębną w stosunku do strumienia lub nawet $\mathrm{w}$ jego obrębie) - nie ma $\mathrm{w}$ ogóle mow $\mathrm{y}^{24}$.

Powróciliśmy więc okrężną drogą do zagadnienia podjętego wcześniej. Fenomen widzenia w przypadku obrazu prowokuje do postawienia pytań, które zagadnienia epistemołogiczne czynią problemem antropologicznym. Czy fundującą podstawą aktu percepcji jest podmiot, który w samooczywistości dla siebie poprzedza każde możliwe widzenie? Czy akt widzenia może być prostym uchwyceniem „że coś jest”, czy zawsze już na wstępie jest zreflektowany ku temu kto widzi? Czy percepcja jest zawsze związana $\mathrm{z}$ apercepcją?

${ }^{23}$ P. Ricoeur, Fenomenologia $i$ hermeneutyka, przeł. M. Drwięga, „Kwartalnik Filozoficzny", t. XXIV, z. 3, s. 164.

${ }^{24}$ R. Ingarden, Spór o istnienie świata, t. II, cz. 1, Warszawa, s. 163. 
Nasze przeświadczenia $\mathrm{w}$ tej sprawie mają niewątpliwie wpływ na to, w jaki sposób rozumiemy doświadczenie obrazu, w jaki sposób je wykładamy i interpretujemy. Jeżeli pojmuję swoją podmiotowość w duchu Kantowskim, to nie wątpię o tym, iż zawsze „w syntetycznej pierwotnej jedności apercepcji jestem świadom samego siebie"25. Czy jednak ta pewność - jest tym samym, co oczywistość własnego Ja - i czy rzeczywiście oczywistość bycia tym Ja towarzyszy nam trwale i niezmiennie? Jak od strony fenomenologicznej kształtuje się na przykład „przedstawienie Ja myślę" w angażującej mnie głęboko aktywności? Jak wygląda, kiedy bywam pochłonięty lekturą książki, oglądanym filmem? Kant mówi wszak, że apercepcja będąca obecnością podmiotu dla siebie we wszystkim, co czyni, to rodzaj umysłowego przedstawienia, które jest wynikiem myślenia, a nie intuitywnym oglądaniem ${ }^{26}$. Myślące ego to wszakże odmienny sposób istnienia podmiotu niż żywa jaźń, która - jak to pokazuje doświadczenie obrazu - w angażującym doświadczeniu potrafi się zatracić.

${ }^{25}$ I. Kant, Krytyka czystego rozumu, t. I, Warszawa 1957, s. 266.

${ }_{26} \mathrm{~W}$ przypisie do powyższego stwierdzenia Kant dodaje: „Myślą wyrażam akt określenia mego bytu. Byt jest więc już przez to dany, lecz nie jest przez to jeszcze dany sposób, w jaki mam go określić, tzn. w jaki mam uznać w sobie istnienie różnorodności do niego przynależnej”. Tamże, s. 267. To intrygująca uwaga. Po pierwsze - to, że jestem sam sobie dany, to implikacja refleksji. Akt określenia własnego bytu implikuje, że jest się już wprzód sobie danym. W refleksji odkrywam zatem Ja jako zatożone. 